\title{
RESENHA
}

\section{Educação Superior como bem público: um testemunho latino-americano}

\begin{abstract}
Pablo Pereira ${ }^{1}$
Universidade Regional de Blumenau (FURB); Bolsista do Programa de Bolsas Universitárias de Santa Catarina UNIEDU/Pós-graduação; Membro do Grupo de Estudos e Pesquisas em Educação Superior (GEPES/FURB) e da Rede lberoamericana de Pesquisas em Políticas e Processos de Educação Superior (RIEPPES/Unoesc)
\end{abstract}

DIAS, M. A. R. Educação Superior como bem público: perspectivas para o centenário da Reforma de Córdoba. Montevidéu: AUGM, 2017. 160 p.

No livro Educação Superior como bem público: perspectivas para o centenário da Reforma de Córdoba, publicado pela Associação de Universidades Grupo Montevidéu (AUGM), em 2017, Marco Antonio Rodrigues Dias, professor titular aposentado da UnB, proporciona aos leitores um conjunto coeso e coerente de 24 testemunhos acadêmicos, organizados em 160 páginas. Análises permeadas de aspectos históricos, reflexões sociais, denúncias econômicas e políticas, perspectivas e desafios latino-americanos, no que diz respeito à Educação Superior como bem público, dão a tônica dos testemunhos, os quais são fundamentais para a compreensão do cenário universitário atual não só latino-americano, mas também global.

Vale destacar que essas análises testemunhais são frutos de uma longa biografia dedicada não só ao Brasil, nas áreas da comunicação, educação e política, mas também a organismos internacionais, a exemplo das atuações de Dias, entre outras tantas que poderiam ser mencionadas, como diretor da Divisão de Ensino Superior da Unesco (Paris), no período de 1981 a 1999, coordenador principal da Conferência Mundial sobre Educação Superior, em 1998, e conselheiro especial do reitor da Universidade das Nações Unidas (UFU), de 2000 a 2009.

\footnotetext{
Mestrando no Programa de Pós-graduação em Educação da Universidade Regional de Blumenau (FURB); Graduado em Letras pela Uniasselvi.
} 
Ademais, a relevância de tal obra, prefaciada por Álvaro Maglia, Secretário Executivo da AUGM, e Paulo Afonso Burmann, Professor Titular e Reitor da Universidade Federal de Santa Maria (UFSM), explica-se na decisão do Conselho de Reitores da AUGM de considerar o texto como sua contribuição ao processo de constituição da Conferência Regional sobre o Ensino Superior (CRES) 2018. Além de dois prefácios, da introdução e de 24 testemunhos, essa obra apresenta, como anexo, um resumo da Declaração Mundial sobre o Ensino Superior de 1998.

Antes de prosseguir, é importante nos atermos por um momento ao título da obra, cuja essência se dá na defesa, apresentada por Marco Antonio Rodrigues Dias em seus testemunhos, de uma Educação Superior como bem público, a qual se baseia em três princípios:

a) igualdade: todos têm direito ao serviço público, sem distinção;

b) continuidade ou permanência: o serviço público deve responder, de forma permanente, sem interrupção, às necessidades de todos os cidadãos;

c) adaptabilidade ou flexibilidade: o serviço público deve adaptarse à evolução da sociedade.

Posto isso, vamos aos testemunhos. No primeiro deles, Dias afirma que, nas últimas décadas, o Pensamento único, patrocinado por aqueles que dominam a vida política e econômica, estimulou mudanças nas instituições e no comportamento dos indivíduos, por meio da aplicação da teoria da modernização, a qual se baseia num pressuposto etnocêntrico ocidental. Nesse contexto, a globalização se consolidou, apresentando-se como um processo que visa a facilitar a mobilidade de ideias, pessoas, bens e serviços. Esse fenômeno, contudo, fortaleceu a interdependência e enfraqueceu a noção de Estado. $\mathrm{Na}$ área econômica, por exemplo, os polos dominantes controlam o conhecimento e os serviços, enquanto os polos periféricos permanecem dependentes.

Ainda sobre o aspecto econômico, no testemunho intitulado Evoluções nos Organismos Internacionais, o autor lembra o leitor de que a adaptação ao 
Ensino Superior dos princípios econômicos do consenso de Washington teve o Banco Mundial (BM) como seu principal agente de promoção, denotando os riscos da linha tênue que separa o acesso ao conhecimento da mercantilização da educação. Vale ressaltar que outros organismos internacionais, como a Organização para Cooperação e Desenvolvimento Econômico (OCDE), o Fundo Monetário Internacional (FMI), a Comissão Europeia e a Organização Mundial do Comércio (OMC), também promoveram tal adaptação.

Na sequência, em $A$ imposição de um modelo, Dias aponta que o modelo de universidade americano se tornou o sistema dominante no mundo. No entanto, nem para os Estados Unidos esse modelo parece ser mais adequado atualmente. Ao enfraquecer o currículo em artes liberais (liberal arts), o país norte-americano transformou a educação em produto e os estudantes em clientes, não existindo, com isso, quaisquer preocupações com a formação do cidadão. Além disso, alerta o autor, esse sistema dominante apresenta outros elementos negativos, como queda de qualidade dos diplomados e explosão da dívida das universidades e dos estudantes.

Em meio a testemunhos, nos quais o autor examina criticamente processos interconectados acerca de modelos educacionais, sistemas de classificação das universidades, mercantilização e acordos comerciais, dificuldades de financiamento, democratização do conhecimento, cooperação solidária, acreditação transfonteiriça, educação superior como bem público, vislumbramos apontamentos assertivos, no testemunho Processo de Bolonha, sobre um dos principais paradoxos da era moderna: cooperar versus competir.

A Declaração de Bolonha inaugurou um dos processos universitários que melhor caracteriza o atual momento da Educação Superior no mundo, trazendo à tona justamente a ideia de cooperação com o intuito de competição (e sobrevivência). Esse processo regionalizado diz respeito a uma reforma universitária dos sistemas de ensino superior nos países pertencentes à União Europeia (UE), a qual implantou um sistema único que permite facilitar a mobilidade acadêmica e alcançar a homogeneização dos títulos, certificados e diplomas. Para tanto, o seu conceito fundamental apresenta-se vinculado à ideia de comparação e de equivalência entre os estudos e à importância da "empregabilidade" e do mercado de trabalho. 
No testemunho intitulado Centenário de Córdoba, por sua vez, o autor desloca as discussões para a América Latina. A Reforma de Córdoba, um movimento iniciado, em 1918, na Argentina, sistematizou-se um conjunto de princípios que se transformaram em referência para ações, como a defesa das liberdades acadêmicas e da autonomia universitária, a insistência na formação integral do ser humano, a necessidade de transferir à sociedade os conhecimentos que as instituições de ensino superior têm ou produzem, entre outros. De acordo com Dias, o centenário de Córdoba possibilita ao mundo acadêmico latino-americano refletir sobre os desafios contemporâneos e atualizar esse marco, cuja base já existe na Declaração de 1918 e, em termos universais, na declaração da Conferência Mundial de Ensino Superior (CMES) de 1998, complementada pela declaração da Conferência Regional sobre o Ensino Superior (CRES) de 2008.

Por fim, em A título de conclusão, a compreensão de que os países da América Latina necessitam de uma urgente integração de suas instituições universitárias, apesar dos momentos difíceis e paradoxais da atualidade, nos quais a dicotomia entre a mercantilização da educação, submissa ao mercado do hemisfério norte, e o acesso amplo ao conhecimento norteia perigosamente discussões não só acadêmicas, mas também econômicas e políticas, parece-me ser o principal alerta do autor em sua obra. Sem essa integração, visando a uma sociedade latino-americana mais justa e independente, condenará o modelo educação da região a "permanecer imitando, copiando, sem capacidade de criar e de ser independente", segundo o autor.

Vista assim, a leitura de Educação Superior como bem público: perspectivas para o centenário da Reforma de Córdoba resultou na seguinte reflexão: qual é o lugar da América Latina, em especial do Brasil, no mundo? Parece-me que os latino-americanos não sabem o que querem, não sabem para onde ir; e não concluo isso baseado exclusivamente em políticas governamentais. Aliás, é perceptível ao longo da leitura da obra que nem a existência da proximidade geográfica entre os países latino-americanos, nem as tentativas de integração com os demais países periféricos ganham amplo espaço nas estratégias das universidades. Da mesma forma, o processo de imitação dos modelos educacionais europeus ou norte-americanos acaba por 
apresentar inúmeras dificuldades de implantação na América Latina, dando a impressão de que tudo fica por acontecer.

Logo, sob a perspectiva de uma tese que defende a urgência de uma tomada de decisão em tempos de ambígua globalização da economia e da educação, recomendo a leitura dos testemunhos latino-americanos de Marco Antonio Rodrigues Dias para estudantes de graduação e pós-graduação, bem como, e principalmente, para professores, pesquisadores e gestores universitários. Afinal, tornam-se prementes ações que visem à adaptação de um novo modelo de universidade à realidade dos países da América Latina.

Recebida em 27 de setembro de 2018 Aceita em 01 de novembro de 2018

Endereços para correspondência: Universidade Regional de Blumenau, Programa de Pós-Graduação em Educação, Rua Antonio da Veiga, 140, Campus 1, Sala I-306, Itoupava Seca, 89030-90, Blumenau, Santa Catarina, Brasil; pablo.professor@gmail.com 
